\title{
DEPENDENCE OF CATHEPSIN L - INDUCED CORONARY ENDOTHELIAL DYSFUNCTION UPON ACTIVATION OF NAD(P)H OXIDASE
}

\author{
Fan Zhang ${ }^{*}$, Yang Zhang ${ }^{*}$, and Pin-Lan Li \\ Department of Pharmacology \& Toxicology, Medical College of Virginia, Virginia Commonwealth \\ University, VA 23298
}

\begin{abstract}
Cathepsin $\mathrm{L}$ is a cysteine protease that can generate endogenous endostatin in vascular and epithelial basement membranes and importantly participates in a variety of pathophysiological processes. The present study was designed to determine whether this cathepsin L-derived endogenous endostatin alters endothelium-dependent vasodilator responses in coronary arteries via NAD $(\mathrm{P}) \mathrm{H}$ oxidase activation. In isolated and perfused small bovine coronary arteries, administration of cathepsin L $(200 \mathrm{ng} / \mathrm{ml})$ markedly attenuated endothelium-dependent vasodilator responses to bradykinin or A23187 by $56.16 \pm 9.58 \%$ and $68.95 \pm 10.32 \%$, respectively. This inhibitory effect of cathepsin L on endothelium-dependent vasodilator responses could be significantly reversed by pre-incubation of the arteries with $\mathrm{O}_{2}^{-\cdot}$ scavenger, tiron, or neutralizing anti-endostatin antibody. By fluorescent ELISA assay, cathepsin L dose-dependently increased endostatin production in coronary arteries. In situ high speed dual wave length switching fluorescent microscopic imaging showed that cathepsin L decreased bradykinin- and A23187-induced NO levels in the intact endothelium, but it had no effect on $\mathrm{Ca}^{2+}$ response to these vasodilators. This cathepsin $\mathrm{L}$-induced reduction of $\mathrm{NO}$ was restored by the pretreatment of an anti-endostatin antibody. Electron spin resonance (ESR) analysis demonstrated that cathepsin $\mathrm{L}$ increased $\mathrm{O}_{2}^{--}$production which could be markedly attenuated by the $\mathrm{NAD}(\mathrm{P}) \mathrm{H}$ oxidase inhibitors, apocynin or anti-endostatin antibody. It is concluded that endostatin could be endogenously produced in coronary arteries when cathepsin $\mathrm{L}$ is increased and that this cathepsin L-derived endostatin, if excessive, may result in endothelial dysfunction through enhanced production of $\mathrm{O}_{2}^{-\cdot}$ due to $\mathrm{NAD}(\mathrm{P}) \mathrm{H}$ oxidase activation.
\end{abstract}

\section{Keywords}

Proteinase; angiogenesis inhibitor; coronary circulation; endothelium; free radicals

\section{INTRODUCTION}

Cathepsins, known as cysteine proteases, have been found in many types of cells from plants to animals, which share the same features of endosomal targeting motifs, namely, acidic $\mathrm{pH}$

Send Correspondence and Reprint Request to: Pin-Lan Li, M.D, Ph.D. Department of Pharmacology and Toxicology, Medical College of Virginia, Virginia Commonwealth University, 410 N $12^{\text {th }}$, Richmond, VA 23298, Tel: (804) 828-4793, Fax: (804) 828-2117, E-mail: E-mail: pli@vcu.edu.

Both contributed equally to this work and shared the first authorship.

Publisher's Disclaimer: This is a PDF file of an unedited manuscript that has been accepted for publication. As a service to our customers we are providing this early version of the manuscript. The manuscript will undergo copyediting, typesetting, and review of the resulting proof before it is published in its final citable form. Please note that during the production process errors may be discovered which could affect the content, and all legal disclaimers that apply to the journal pertain. 
optima and autocatalytic activation. Physiologically, cathepsins have a vital role in a number of events, such as antigen presentation(Nakagawa et al., 1998), bone absorption (Saftig et al., 1998), biosynthesis of peptide neurotransmitter and hormones (Hook et al., 2004). Under pathological conditions, these elastinolytic cathepsins are highly expressed as observed in atherosclerosis, chronic obstructive pulmonary disease, and malignant tumors (Cimerman et al., 2001; Kitamoto et al., 2007; Liotta et al., 1991). Among these cathepsins, cathepsin L is considered as a potent isoform contributing to the process of atherogenesis. Although the underlying mechanism is not fully understood, some observations have suggested that cathepsin L participates in atherosclerosis by degradation of elastin and collagen and consequent regulation of blood-borne leukocyte transmigration and lesion progression. In particular, loss of collagen XVIII under action of cathepsin L was found to importantly enhance neovascularization and vascular permeability in atherosclerosis(Moulton et al., 2004).

More recently, collagen XVIII as the core protein of a heparin sulfate proteoglycan in vascular and epithelial base (Felbor et al., 2000; Oh et al., 1994; Sasaki et al., 1998) has been shown to contain a domain as the substrate of cathepsin L. It was demonstrated that activation of cathepsin $\mathrm{L}$ causes the cleavage of peptide bonds within the protease-sensitive hinge region of the NC1 domain of collagen XVIII, leading to the release of endostatin (Felbor et al., 2000; Oh et al., 1994), a 20-kDa proteolytic fragment (O'Reilly et al., 1997). To date, endostatin has been reported as one of the most potent endothelial cell-specific inhibitors of angiogenesis and tumor growth in vivo (Boehm et al., 1997; Dhanabal et al., 1999b; O'Reilly et al., 1997). This collagen XVIII-derived antiangiogenetic factor also has been demonstrated to inhibit endothelial cell growth or induce apoptosis in vitro (Dhanabal et al., 1999a; O'Reilly et al., 1997). Recent studies in our laboratory and by others have demonstrated that exogenous endostatin reduces nitric oxide (NO) production in intact coronary arterial endothelium or in cultured umbilical vein endothelial cells(Urbich et al., 2002) which may induce endothelial dysfunction preceding structural or morphological damages such as apoptotic or necrotic injury of these cells. However, so far there is no direct evidence that endogenously produced endostatin does produce endothelial dysfunction.

In the present study, we first tested whether endostatin could be produced from coronary arterial preparation via cathepsin $\mathrm{L}$ and cathepsin $\mathrm{L}$-derived endostatin reduces endothelial NO production in intact coronary artery and thereby impairs endothelium-dependent vasodialtion in coronary arteries. We then further explored a $\mathrm{Ca}^{2+}$-independent and superoxide $\left(\mathrm{O}_{2}{ }^{-}\right)$associated mechanism reducing NO in coronary endothelial cells. Finally, we examined the contribution of $\mathrm{NAD}(\mathrm{P}) \mathrm{H}$ oxidase to the effects of cathepsin L-derived endostatin in inducing $\mathrm{O}_{2}^{-\cdot}$ production and $\mathrm{NO}-\mathrm{O}_{2}{ }^{-}$interactions.

\section{MATERIALS AND METHODS}

\section{Dissection of small coronary arteries}

Fresh bovine hearts were obtained from a local abattoir. Small intramural coronary arteries from the branches of left anterior descending artery were carefully dissected and placed in the ice-cold physiological saline solution (PSS) containing the following composition (in $\mathrm{mM}$ ): $\mathrm{NaCl}, 119 ; \mathrm{KCl}, 4.7 ; \mathrm{CaCl}_{2}$, 1.6; $\mathrm{MgSO}_{4}, 1.17 ; \mathrm{NaH}_{2} \mathrm{PO}_{4}, 1.18 ; \mathrm{NaHCO}_{3}$, 24; EDTA, 0.026; and glucose, $5.5, \mathrm{pH} 7.4$. For microperfusion experiments, the artery segments $(250 \pm 50 \mu \mathrm{m}$ in lumen diameter; 5-8 $\mathrm{mm}$ in length) were carefully cleaned off of fat and connective tissues under a dissection microscope and placed in cold PSS until cannulation. For fluorescence imaging experiments, small coronary arteries (300-500 $\mu \mathrm{m}$ in lumen diameter) were prepared in a similar way and kept in ice-cold modified Hanks' buffered salt solution containing (in mM) $137 \mathrm{NaCl}, 5.4 \mathrm{KCl}, 4.2 \mathrm{NaHCO}_{3}, 3 \mathrm{Na}_{2} \mathrm{HPO}_{4}, 0.4 \mathrm{KH}_{2} \mathrm{PO}_{4}, 1.5 \mathrm{CaCl}_{2}, 0.5 \mathrm{MgCl}_{2}, 0.8$ $\mathrm{MgSO}_{4}, 10$ glucose, 10HEPES, pH 7.4 (Li et al., 1999; Yi et al., 2002; Zhang et al., 2006b). 


\section{ELISA immunofluorescence analysis of endostatin production in coronary arteries by cathepsin L}

The left anterior descending artery from fresh bovine heart was dissected and homogenized in ice-cold HEPES buffer (pH 7.4) containing (in mM) 20 HEPES, 1 EDTA, 255 sucrose with complete protease inhibitor cocktail (Roche Diagnostics). After centrifugation of the homogenate at $6,000 \mathrm{~g}$ for $5 \mathrm{~min}$ at $4^{\circ} \mathrm{C}$, the supernatant containing the membrane protein and cytosolic components was collected and termed as homogenate. $100 \mu \mathrm{g}$ homogenate protein was incubated with $100 \mathrm{ng}$ or $200 \mathrm{ng}$ cathepsin L for 1 hour. Endostatin level was determined using Quantikine endostatin immunoassay kit (R\&D Systems, Minneapolis, MN) according to the manufacturer's instructions.

\section{Vascular reactivity in in vitro perfused small coronary arteries}

Dissected arteries were transferred to a water-jacketed perfusion chamber and cannulated with two glass micropipettes at their in situ length as described previously (Campbell et al., 2002; Geiger et al., 2000; Zhang et al., 2005). The outflow cannula was clamped and the arteries were pressurized to $60 \mathrm{~mm} \mathrm{Hg}$ and equilibrated in PSS at $37^{\circ} \mathrm{C}$. PSS in the bath was continuously bubbled with a gas mixture of $95 \% \mathrm{O}_{2}$ and $5 \% \mathrm{CO}_{2}$ throughout the experiment. After a 1-hour equilibration period, the arteries were precontracted with a thromboxane $\mathrm{A}_{2}$ analog, U-46619 $(2-20 \mathrm{nM})$ until a $\sim 50 \%$ of decrease in resting diameter was reached. Once steady-state contraction was obtained, cumulative dose-response curves to the endothelium-dependent vasodilator bradykinin (BK, $10^{-10}$ to $\left.10^{-6} \mathrm{~mol} / \mathrm{L}\right)$ or $\mathrm{A} 23187\left(10^{-9}\right.$ to $\left.10^{-5} \mathrm{~mol} / \mathrm{L}\right)$ were determined by measuring changes in internal diameter. All drugs were added into the bath solution unless otherwise indicated. The vasodilator response was expressed as the percent relaxation of U-46619-induced pre-contraction based on changes in arterial internal diameter. The arteries were excluded from statistical analysis if the contractile response to U46619 was $<40 \%$ or dilator response to bradykinin $<80 \%$. Internal arterial diameter was measured with a video system composed of a stereomicroscope (Leica MZ8), a charge-coupled device camera (KP-MI AU, Hitachi), a video monitor (VM-1220U, Hitachi), a video measuring apparatus (VIA-170, Boeckeler Instrument), and a video printer (UP890 MD, Sony). The arterial images were recorded continuously with a videocassette recorder (M-674, Toshiba). All of the drugs were added into the bath solution unless otherwise indicated. The vasodilator response to bradykinin and A23187 was expressed as the percent relaxation of U46619-induced precontraction based on changes in the ID.

\section{Electromagnetic Spin Resonance (ESR) Spectrometric Detection of $\mathrm{O}_{2}{ }^{\cdot-}$}

Primarily cultured bovine coronary artery endothelial cells were gently collected and suspended in modified Krebs-HEPES buffer containing deferoxamine $(100 \mu \mathrm{M}$; metal chelator). Approximately $1 \times 10^{-6}$ cells were then incubated with cathepsin $\mathrm{L}(200 \mathrm{ng} / \mathrm{ml})$ for 1 - hour or endostatin $(100 \mathrm{nM})$ for $30 \mathrm{~min}$ in the presence of endostatin antibody $(10 \mu \mathrm{g} / \mathrm{ml})$ or apocynin $(100 \mu \mathrm{M})$, an $\mathrm{NAD}(\mathrm{P}) \mathrm{H}$ oxidase inhibitor, then mixed with $1 \mathrm{mM}$ of the $\mathrm{O}_{2}{ }^{-}$specific spin trap 1-hydroxy-3-methoxycarbonyl-2,2,5,5-tetramethylpyrrolidine (CMH). The cell mixture was subsequently loaded in glass capillaries and immediately kinetically analyzed for $\mathrm{O}_{2}{ }^{--}$production at each minute for $10 \mathrm{~min}$ (Noxygen Science Transfer \& Diagnostics $\mathrm{GmbH}$ ). The ESR settings were as follows: biofield, 3,350; field sweep, $60 \mathrm{G}$; microwave frequency, $9.78 \mathrm{GHz}$; microwave power, $20 \mathrm{~mW}$; modulation amplitude, $3 \mathrm{G}$; 4,096 points of resolution; receiver gain, 100; and kinetic time, $10 \mathrm{~min}$ (Jin et al., 2008b; Zhang et al., 2008). 


\section{Fluorescence imaging analysis of $\mathrm{NO}$ levels and $\left[\mathrm{Ca}^{2+}\right]_{i}$ in the intact endothelium of bovine coronary arteries}

Simultaneous recording of NO level and $\left[\mathrm{Ca}^{2+}\right]_{\mathrm{i}}$ in the intact endothelium of coronary was performed with a protocol developed currently in our laboratory, in which fura 2 (Zhang et al., 2004) was used as the indicator for $\left[\mathrm{Ca}^{2+}\right]_{\mathrm{i}}$ and 4,5-diaminofluorescein (DAF-2) as the probe for intracellular NO levels (Kojima et al., 1998; Yi et al., 2002; Zhang et al., 2005). In brief, small bovine coronary artery (300-500 $\mu \mathrm{m}$ in diameter) with the lumen open along its longitudinal axis was loaded with DAF-2 diacetate $(10 \mu \mathrm{M})$ and fura 2-AM $(10 \mu \mathrm{M})$ in Hanks buffer containing (in mM), $137 \mathrm{NaCl}, 5.4 \mathrm{KCl}, 4.2 \mathrm{NaHCO}_{3}, 3 \mathrm{Na}_{2} \mathrm{HPO}_{4}, 0.4 \mathrm{KH}_{2} \mathrm{PO}_{4}, 1.5$ $\mathrm{CaCl}_{2}, 0.5 \mathrm{MgCl}_{2}, 0.8 \mathrm{MgSO}_{4}, 10$ glucose, and 10 HEPES; $\mathrm{pH} 7.4$ for $40 \mathrm{~min}$ at room temperature, then transferred into recording chamber with the vessel lumen side facing a $\times 20$ phase/fluor objective (Nikon Diaphot) for individual endothelial cells visualization. The dynamic changes in $\left[\mathrm{Ca}^{2+}\right]_{\mathrm{i}}$ and NO level within the cells were analyzed with the excitation wavelengths of $340 \pm 10$ or $380 \pm 10$ (both for fura 2), and $480 \pm 20$ (for DAF-2) nm provided by a high-speed wavelength switcher (Lambda DG-4; Sutter, Novato, CA), and emission wavelength of $510 \pm 20 \mathrm{~nm}$ for fura 2 or $535 \pm 25 \mathrm{~nm}$ for DAF-2 by a high-speed rotating filter wheel (Lambda 10-2; Sutter). The fluorescence images were captured by a digital camera (SPOT RT Monochrome; Diagnostic Instruments). A metafluor imaging and analysis software (Universal Imaging) was used to acquire, digitize, and store the images and for off-line processing and statistical analysis.

The fluorescence ratio of excitation at $340 \mathrm{~nm}$ to that at $380 \mathrm{~nm}$ (F340/F380) was determined after background subtraction, and $\left[\mathrm{Ca}^{2+}\right]_{\mathrm{i}}$ was calculated by using the following equation: $\left[\mathrm{Ca}^{2+}\right]_{\mathrm{i}}=\mathrm{Kd}[(\mathrm{R}-\mathrm{Rmin}) /(\mathrm{Rmax}-\mathrm{R})]$, where $\mathrm{Kd}$ for the fura $2-\mathrm{Ca}^{2+}$ complex is $224 \mathrm{nM}$; $\mathrm{R}$ is the fluorescence ratio (F340/F380); Rmax and Rmin are the maximal and minimal fluorescence ratios measured by addition of $10 \mu \mathrm{M}$ of $\mathrm{Ca}^{2+}$ ionophore ionomycin to $\mathrm{Ca}^{2+}$ replete solution ( $2.5 \mathrm{mM} \mathrm{CaCl}_{2}$ ) and $\mathrm{Ca}^{2+}$-free solution ( $5 \mathrm{mM} \mathrm{EGTA}$ ), respectively; and $\mathrm{R}$ is the fluorescence ratio at 380-nm excitation determined at Rmin and Rmax, respectively (Grynkiewicz et al., 1985; Yi et al., 2002).

The intracellular NO production was expressed as a change of DAF-2 (Kojima et al., 1998) fluorescence $(\mathrm{F})$ relative to its basal value $\left(\mathrm{F}_{0}\right)$ at excitation/emission of $480 / 535 \mathrm{~nm}$. Since NO doesn't dissociate from DAF-2 once this dye reacts with NO, the detected NO-sensitive DAF-2 fluorescence actually represents a cumulative amount of NO within the cells. To more accurately present the relationship between $\mathrm{NO}$ production and $\mathrm{Ca}^{2+}$, we performed a differential conversion of time-dependent NO-DAF-2 fluorescence curve to calculate NO production rate, df/dt using the following equation as we described previously (Yi et al., 2002; Zhang et al., 2005):

$$
\frac{\mathrm{df}}{\mathrm{dt}}=\frac{\mathrm{a}}{\mathrm{b}} \times e^{\left[e\left(\frac{\mathrm{t}-\mathrm{t}_{0}}{\mathrm{~b}}\right)+\frac{\mathrm{t}-\mathrm{t}_{0}}{\mathrm{~b}}\right]}
$$

Where $\mathrm{df} / \mathrm{dt}$ is the NO production rate as measured by differential conversion of fluorescent intensity, $\mathrm{t}$ is time, $\mathrm{t}_{0}$ is time when $\mathrm{BK}$ or $\mathrm{A} 23188$ is added, and $\mathrm{a}$ and $\mathrm{b}$ are constants that define the shape for a specific fitting curve of BK or A23187 response and can be calculated with the curve-fitting program of SigmaPlot 8.0. e is natural logarithm.

\section{Statistics}

Data are presented as means \pm SE, and the significance of the differences in mean values between and within multiple groups was examined using an analysis of variance for repeated measures followed by a Duncan's multiple range test. $P<0.05$ was considered statistically significant. 


\section{RESULTS}

\section{Concentration-Dependent Effects of Endostatin on BK or A23187-induced Vasodilator Responses in Small Coronary Arteries}

Concentration-response curves of the endothelium-dependent vasodilation induced by BK or A23187 were determined in small coronary arteries before and after endostatin treatment.

Figure 1 shows that both BK and A23187 produced a concentration-dependent vasorelaxation in these small coronary arteries with a maximal response at the concentrations of $10^{-6}$ or $10^{-5} \mathrm{M}$, respectively. Incubation of the arteries with endostatin ( 30 or $90 \mathrm{nM}$ perfused into the lumen) markedly decreased basal arterial diameters and dose-dependently attenuated the BKor A23187-induced increase in arterial diameters, maximally by $34.14 \pm 5.09 \%$ and $62.36 \pm$ $6.16 \%$ in BK group, and $34.28 \pm 7.77 \%$ and $67.20 \pm 6.30 \%$ in A23187 group, correspondingly.

\section{Cathepsin L-induced Endostatin Production in Bovine Coronary Artery}

By ELISA analysis, we examined whether Cathepsin L stimulates endogenous endostatin production in bovine coronary arteries. Figure 2 shows that cathepsin L could dose-dependently increase endostatin production in arterial homogenate preparations. The tissue level of endostatin in these arteries was markedly increased by about $50 \%$ and $130 \%$ when 100 and $200 \mathrm{ng} / \mathrm{mL}$ cathepsin $\mathrm{L}$ was added into the reaction mixtures, respectively.

\section{Effects of Cathepsin L on BK or A23187-induced Vasodilator Responses in Small Coronary Arteries}

The results above demonstrated that endostatin could impair endothelium-dependent vasodilation and that coronary arteries were able to produce endostatin enzymatically via cathepsin L. To further address the functional significance of endogenously produced endostatin, we also examined the effects of this protease on BK or A23187-induced vasodilation response in small coronary arteries. It was found that cathepsin L significantly decreased BK or A23187 induced vasodilation with the maximal attenuation of arterial diameters by $56.16 \pm 9.58 \%$ and $68.95 \pm 10.32 \%$ in BK and A23187-treated arteries, respectively. After pretreatment of the arteries with an anti-endostatin antibody $(10 \mu \mathrm{g} / \mathrm{ml})$, cathepsin $\mathrm{L}$ almost failed to attenuate the endothelium-dependent vasodilation to $\mathrm{BK}$ and A23187 in these small coronary arteries.

\section{Cathepsin L uncouples BK or A23187-induced $\mathrm{Ca}^{2+}$ Release and NO Production in the Endothelium of Intact Bovine Coroanry Arteries}

To further explore the mechanism mediating the action of cathepsin $\mathrm{L}$, we determined whether cathepsin $\mathrm{L}$ produces endostatin that reduces $\mathrm{NO}$ levels in the endothelium in a $\mathrm{Ca}^{2+}$ independent manner. By simultaneously monitoring $\mathrm{NO}$ and $\left[\mathrm{Ca}^{2+}\right]_{i}$ with fluorescence microscopic imaging technique, we analyzed the $\mathrm{NO}$ and $\left[\mathrm{Ca}^{2+}\right]_{\mathrm{i}}$ level in the intact coronary arterial endothelium when exposed cathepsin L. As summarized in Figure 4, BK increased $\left[\mathrm{Ca}^{2+}\right]_{\mathrm{i}}$ by 5.6 folds and DAF fluorescence by 23.5 folds (control vs. BK) in the absence of cathepsin L. When the arterial endothelium was pretreated with cathepsin L, BK no longer increased NO but still stimulated an increase in $\left[\mathrm{Ca}^{2+}\right]_{\mathrm{i}}$ (cathepsin $\mathrm{L}+\mathrm{BK}$ ). However, in the presence of both anti-endostatin antibody $(10 \mu \mathrm{g} / \mathrm{ml})$ and cathepsin $\mathrm{L}(200 \mathrm{ng} / \mathrm{ml})$, BK-induced NO production was restored to the level when the arteries were stimulated by BK without cathepsin L treatment. Similarly, A23187 at $1 \mu \mathrm{M}$ increased $\left[\mathrm{Ca}^{2+}\right]_{\mathrm{i}}$ by 7.2 folds and DAF fluorescence by 17.0 folds. Pretreatment of arteries with cathepsin L inhibited A23187-induced NO production, but it had no significant effect on the $\mathrm{Ca}^{2+}$ response. Furthermore, when the arteries were pretreatred with an anti-endostatin antibody $(10 \mu \mathrm{g} / \mathrm{ml})$, the action of cathepsin $\mathrm{L}$ attenuating A23187-induced NO production were blocked. These results were summarized in Figure 4B. 


\section{Association of Cathepsin L-attenuated Coronary Dilation with $\mathrm{O}_{2} \cdot$ - Production}

Given no evidence that endostatin reduces $\mathrm{NO}$ level in $\mathrm{Ca}^{2+}$-dependent activation of nitric oxide synthase (NOS) (Yi et al., 2002), we examined whether cathepsin $\mathrm{L}$ increases $\mathrm{O}_{2}{ }^{-}$ production and thereby decreases the NO bioavailability, leading to impairment of endothelium-dependent vasodilation. It was found that application of $\mathrm{O}_{2}{ }^{-{ }^{-}}$dismutase mimetic (SOD), tiron $(1 \mathrm{mM})$ to the bovine coronary artery markedly reduced cathepsin L-induced impairment of the vasodilator response to either BK or A23187 (Figure 5).

\section{Cathepsin $\mathrm{L}$ induced $\mathrm{O}_{2} \cdot-$ Production from Bovine Coronary Arterial Endothelial Cells}

Using electron spin resonance spectrometric analysis, $\mathrm{O}_{2}{ }^{--}$production in coronary arterial endothelial cells induced by cathepsin $\mathrm{L}$ or endostatin was tested. Figure 6A depicts representative ESR spectrographs of $\mathrm{O}_{2}{ }^{--}$production as trapped by $\mathrm{CMH}$ in endothelial cells under different treatments. $\mathrm{O}_{2}{ }^{-}$production in the cells treated with cathepsin $\mathrm{L}$ or endostatin alone was significantly increased by 2.1 or 1.9 folds compared to control. This cathepsin L- or endostatin-induced $\mathrm{O}_{2}{ }^{--}$production was almost blocked by $\mathrm{NAD}(\mathrm{P}) \mathrm{H}$ oxidase inhibitor, Apocynin $(100 \mu \mathrm{M})$, or an anti-endostatin antibody $(10 \mu \mathrm{g} / \mathrm{ml})$. However, Apocynin had no effect on basal production of $\mathrm{O}_{2}{ }^{-}$in endothelial cells without any stimuli (Figure 6B).

\section{DISCUSSION}

The present study demonstrates that cathepsin $L$ promotes endogenous generation of endostatin and attenuates the endothelium-dependent vasodilator response in bovine coronary arteries. And the underlining mechanism is attributed to the increase in endogenous endostatin production, which activates $\mathrm{NAD}(\mathrm{P}) \mathrm{H}$ oxidase and increases $\mathrm{O}_{2}{ }^{--}$generation resulting in decreased NO bioavailability in the endothelium.

Previous studies demonstrated that exogenous endostatin reduces NO level in endothelial cells through inhibition of eNOS activation associated with VEGF (Urbich et al., 2002) or reduction of NO availability associated with $\mathrm{O}_{2}{ }^{--}$production(Jin et al., 2008b; Zhang et al., 2005; Zhang et al., 2006a). However, those studies did not address the physiological significance of this endostatin-induced action. In the present study, we found that endostatin could dosedependently attenuate bradykinin or A23187-induced vasodilation. These results indicate that endostatin-induced endothelial dysfunction could occur no matter whether a receptor-mediated endothelium-dependent vasodilator, BK, or a non-receptor-mediated endothelial NO stimulatory agonist, A23187, was used. Although A23187 bypasses the receptor step and activates eNOS through increase in $\left[\mathrm{Ca}^{2+}\right]_{\mathrm{i}}$, endostatin-induced $\mathrm{O}_{2}{ }^{-}$production may interact with $\mathrm{NO}$ to generate $\mathrm{ONOO}^{-}$impairing this vasodilator response (Zhang et al., 2005).

Functionally, our results demonstrated that endogenously-derived endostatin by cathepsin $\mathrm{L}$ acutely damaged endothelium-dependent vasodilatation. And this endothelial dysfunction has been considered an early event in atherosclerosis(Jin et al., 2008a). It seems that cathepsin Lendostatin pathway may be one of the important mechanisms regulating endothelial function under physiological conditions or participate in the development of endothelial dysfunction when this enzyme system is activated excessively. In this regard, it has been reported that the integrality of vascular and epithelial basement membranes play a vitally protective role in the maintenance of endothelial function and prevention of atherosclerosis (Marneros et al., 2004; Zeng et al., 2005). Impaired barrier function of the aorta due to the proteolysis of collagen XVIII by cathepsin L had been shown to increase influx of lipoproteins across the endothelium in the development of atherosclerosis. Furthermore, when XVIII/endostatin acted as an active component in the intact basement membrane, it could interact with biglycan and LDL, interfere with LDL retention to biglycan and subsequently inhibit the macrophage uptake of biglycanassociated LDL, which consequently inhibits the foam cells formation in the process of 
atherosclerosis (Zeng et al., 2005). All this evidence together suggests that normal XVIII metabolism in vascular basement is of importance in the regulation of endothelial function or vascular function.

By simultaneous in situ monitoring of intracellular $\mathrm{Ca}^{2+}$ and NO, we found that cathepsin Lderived endogenous endostatin uncouples NO production and $\mathrm{Ca}^{2+}$ responses, which is very similar to that which we reported by exogenous endostatin (Zhang et al., 2005). In previous studies, endostatin, the endogenous metabolite of cathepsin L was reported to decrease NO production by inhibition of endothelial nitric oxide synthase (eNOS) (Urbich et al., 2002). However, this phenomenon was observed in anti-angiogenic studies of endostatin, where endostatin inhibits VEGF-induced endothelial cell migration and VEGF-stimulated NO production by dephosphoration of eNOS on Ser 1177 (Urbich et al., 2002). This VEGFmediated action of endostatin may occur when endostatin was used for a relatively long time, which was different from the results obtained with transient exposure of endostatin either by extracellular application or endogenous generation. It is possible that when endostatin is used for a longer time, this antiangiogenic peptide may directly interfere with eNOS activity and thereby produce its anti-angiogenic effects. In the present study, endostatin from cathepsin $\mathrm{L}$ produces an early action that induces endothelial dysfunction by uncoupling NO production and $\mathrm{Ca}^{2+}$ responses without significant changes in NOS activity (Zhang et al., 2005).

To the underlying mechanisms of how cathepsin $\mathrm{L}$-derived endostatin reduces $\mathrm{NO}$ bioavailability, our present studies revealed that overproduction of $\mathrm{O}_{2}{ }^{--}$by cathepsin $\mathrm{L}$ via endostatin contributes to the reduction in $\mathrm{NO}$ bioavailability and subsequently leads to the damage of endothelial function. Interaction of $\mathrm{NO}$ with $\mathrm{O}_{2}{ }^{--}$decreases the bioavailable $\mathrm{NO}$ in the endothelial cells and produces a potent oxidant, peroxynitrite $\left(\mathrm{ONOO}^{-}\right)$, which is a major determinant of endothelial function impairment(Zhang et al., 2005). In cardiovascular systems, several enzymatic sources of $\mathrm{O}_{2}{ }^{--}$exist including $\mathrm{NAD}(\mathrm{P}) \mathrm{H}$ oxidase, xanthine oxidase, mitochondrial respiratory chain, arachidonic acid metabolizing system and uncoupled NO synthase (Boodhwani et al., 2006; Cai and Harrison, 2000). Our recent studies demonstrated that endostatin-activated redox signaling cascade was associated with activation of $\mathrm{NAD}(\mathrm{P}) \mathrm{H}$ oxidase in endothelial cells (Jin et al., 2008b; Zhang et al., 2005; Zhang et al., 2006a). It was shown that $\mathrm{NAD}(\mathrm{P}) \mathrm{H}$ oxidase subunit of gp91phox was able to be aggregated into lipid raft clusters and that this aggregation could form an $\mathrm{NAD}(\mathrm{P}) \mathrm{H}$ oxidase-mediated redox signaling platform, which initiates assembling of other subunits of $\mathrm{NAD}(\mathrm{P}) \mathrm{H}$ oxidase and consequently activates this enzyme to produce $\mathrm{O}_{2}^{\cdot-}$ (Jin et al., 2008a).

In summary, the present study demonstrated that cathepsin L impaired endothelium-dependent vasodilation in coronary arteries through production of endostatin. This pathological action of artery-derived endostatin was associated with $\mathrm{NAD}(\mathrm{P}) \mathrm{H}$ oxidase activation, $\mathrm{O}_{2}{ }^{-}$production, and reduction of NO bioavailability. These findings indicate that a protease-mediated regulation of endothelial function is present in coronary circulation. When such protease action is excessive, endothelial function will be impaired.

\section{Acknowledgments}

This study was supported by grants from the National Institute of Health (HL-57244, HL-91464, HL-75316 and DK-54927).

\section{References}

Boehm T, Folkman J, Browder T, O’Reilly MS. Antiangiogenic therapy of experimental cancer does not induce acquired drug resistance. Nature 1997;390:404-407. [PubMed: 9389480]

Boodhwani M, Nakai Y, Mieno S, Voisine P, Bianchi C, Araujo EG, Feng J, Michael K, Li J, Sellke FW. Hypercholesterolemia impairs the myocardial angiogenic response in a swine model of chronic 
ischemia: role of endostatin and oxidative stress. Ann Thorac Surg 2006;81:634-641. [PubMed: 16427865]

Cai H, Harrison DG. Endothelial dysfunction in cardiovascular diseases: the role of oxidant stress. Circ Res 2000;87:840-844. [PubMed: 11073878]

Campbell WB, Deeter C, Gauthier KM, Ingraham RH, Falck JR, Li PL. 14,15-Dihydroxyeicosatrienoic acid relaxes bovine coronary arteries by activation of $\mathrm{K}(\mathrm{Ca})$ channels. Am J Physiol Heart Circ Physiol 2002;282:H1656-1664. [PubMed: 11959628]

Chwieralski CE, Welte T, Buhling F. Cathepsin-regulated apoptosis. Apoptosis 2006;11:143-149. [PubMed: 16502253]

Cimerman N, Mesko Brguljan P, Krasovec M, Suskovic S, Kos J. Serum concentration and circadian profiles of cathepsins B, H and L, and their inhibitors, stefins A and B, in asthma. Clin Chim Acta 2001;310:113-122. [PubMed: 11498076]

Dhanabal M, Ramchandran R, Waterman MJ, Lu H, Knebelmann B, Segal M, Sukhatme VP. Endostatin induces endothelial cell apoptosis. J Biol Chem 1999a;274:11721-11726. [PubMed: 10206987]

Dhanabal M, Volk R, Ramchandran R, Simons M, Sukhatme VP. Cloning, expression, and in vitro activity of human endostatin. Biochem Biophys Res Commun 1999b;258:345-352. [PubMed: 10329390]

Felbor U, Dreier L, Bryant RA, Ploegh HL, Olsen BR, Mothes W. Secreted cathepsin L generates endostatin from collagen XVIII. Embo J 2000;19:1187-1194. [PubMed: 10716919]

Geiger J, Zou AP, Campbell WB, Li PL. Inhibition of cADP-ribose formation produces vasodilation in bovine coronary arteries. Hypertension 2000;35:397-402. [PubMed: 10642331]

Grynkiewicz G, Poenie M, Tsien RY. A new generation of Ca2+ indicators with greatly improved fluorescence properties. J Biol Chem 1985;260:3440-3450. [PubMed: 3838314]

Hook V, Yasothornsrikul S, Greenbaum D, Medzihradszky KF, Troutner K, Toneff T, Bundey R, Logrinova A, Reinheckel T, Peters C, Bogyo M. Cathepsin L and Arg/Lys aminopeptidase: a distinct prohormone processing pathway for the biosynthesis of peptide neurotransmitters and hormones. Biol Chem 2004;385:473-480. [PubMed: 15255178]

Jin S, Yi F, Zhang F, Poklis JL, Li PL. Lysosomal targeting and trafficking of acid sphingomyelinase to lipid raft platforms in coronary endothelial cells. Arterioscler Thromb Vasc Biol 2008a;28:20562062. [PubMed: 18772496]

Jin S, Zhang Y, Yi F, Li PL. Critical role of lipid raft redox signaling platforms in endostatin-induced coronary endothelial dysfunction. Arterioscler Thromb Vasc Biol 2008b;28:485-490. [PubMed: 18162606]

Kitamoto S, Sukhova GK, Sun J, Yang M, Libby P, Love V, Duramad P, Sun C, Zhang Y, Yang X, Peters C, Shi GP. Cathepsin L deficiency reduces diet-induced atherosclerosis in low-density lipoprotein receptor-knockout mice. Circulation 2007;115:2065-2075. [PubMed: 17404153]

Kojima H, Nakatsubo N, Kikuchi K, Kawahara S, Kirino Y, Nagoshi H, Hirata Y, Nagano T. Detection and imaging of nitric oxide with novel fluorescent indicators: diaminofluoresceins. Anal Chem 1998;70:2446-2453. [PubMed: 9666719]

Li PL, Chen CL, Bortell R, Campbell WB. 11,12-Epoxyeicosatrienoic acid stimulates endogenous monoADP-ribosylation in bovine coronary arterial smooth muscle. Circ Res 1999;85:349-356. [PubMed: 10455063]

Li W, Dalen H, Eaton JW, Yuan XM. Apoptotic death of inflammatory cells in human atheroma. Arterioscler Thromb Vasc Biol 2001;21:1124-1130. [PubMed: 11451740]

Li W, Kornmark L, Jonasson L, Forssell C, Yuan XM. Cathepsin L is significantly associated with apoptosis and plaque destabilization in human atherosclerosis. Atherosclerosis. 2008

Liotta LA, Steeg PS, Stetler-Stevenson WG. Cancer metastasis and angiogenesis: an imbalance of positive and negative regulation. Cell 1991;64:327-336. [PubMed: 1703045]

Marneros AG, Keene DR, Hansen U, Fukai N, Moulton K, Goletz PL, Moiseyev G, Pawlyk BS, Halfter W, Dong S, Shibata M, Li T, Crouch RK, Bruckner P, Olsen BR. Collagen XVIII/endostatin is essential for vision and retinal pigment epithelial function. Embo J 2004;23:89-99. [PubMed: 14685281] 
Moulton KS, Olsen BR, Sonn S, Fukai N, Zurakowski D, Zeng X. Loss of collagen XVIII enhances neovascularization and vascular permeability in atherosclerosis. Circulation 2004;110:1330-1336. [PubMed: 15313955]

Nakagawa T, Roth W, Wong P, Nelson A, Farr A, Deussing J, Villadangos JA, Ploegh H, Peters C, Rudensky AY. Cathepsin L: critical role in Ii degradation and CD4 T cell selection in the thymus. Science 1998;280:450-453. [PubMed: 9545226]

Oh SP, Warman ML, Seldin MF, Cheng SD, Knoll JH, Timmons S, Olsen BR. Cloning of cDNA and genomic DNA encoding human type XVIII collagen and localization of the alpha 1(XVIII) collagen gene to mouse chromosome 10 and human chromosome 21. Genomics 1994;19:494-499. [PubMed: 8188291]

O’Reilly MS, Boehm T, Shing Y, Fukai N, Vasios G, Lane WS, Flynn E, Birkhead JR, Olsen BR, Folkman J. Endostatin: an endogenous inhibitor of angiogenesis and tumor growth. Cell 1997;88:277-285. [PubMed: 9008168]

Saftig P, Hunziker E, Wehmeyer O, Jones S, Boyde A, Rommerskirch W, Moritz JD, Schu P, von Figura $\mathrm{K}$. Impaired osteoclastic bone resorption leads to osteopetrosis in cathepsin-K-deficient mice. Proc Natl Acad Sci U S A 1998;95:13453-13458. [PubMed: 9811821]

Sasaki T, Fukai N, Mann K, Gohring W, Olsen BR, Timpl R. Structure, function and tissue forms of the C-terminal globular domain of collagen XVIII containing the angiogenesis inhibitor endostatin. Embo J 1998;17:4249-4256. [PubMed: 9687493]

Turk B, Stoka V, Rozman-Pungercar J, Cirman T, Droga-Mazovec G, Oresic K, Turk V. Apoptotic pathways: involvement of lysosomal proteases. Biol Chem 2002;383:1035-1044. [PubMed: 12437086]

Urbich C, Reissner A, Chavakis E, Dernbach E, Haendeler J, Fleming I, Zeiher AM, Kaszkin M, Dimmeler S. Dephosphorylation of endothelial nitric oxide synthase contributes to the antiangiogenic effects of endostatin. Faseb J 2002;16:706-708. [PubMed: 11978735]

Yi FX, Zhang AY, Campbell WB, Zou AP, Van Breemen C, Li PL. Simultaneous in situ monitoring of intracellular Ca2+ and NO in endothelium of coronary arteries. Am J Physiol Heart Circ Physiol 2002;283:H2725-2732. [PubMed: 12388315]

Zeng X, Chen J, Miller YI, Javaherian K, Moulton KS. Endostatin binds biglycan and LDL and interferes with LDL retention to the subendothelial matrix during atherosclerosis. J Lipid Res 2005;46:18491859. [PubMed: 15995169]

Zhang AY, Teggatz EG, Zou AP, Campbell WB, Li PL. Endostatin uncouples NO and Ca2+ response to bradykinin through enhanced $\mathrm{O} 2 *$-production in the intact coronary endothelium. Am J Physiol Heart Circ Physiol 2005;288:H686-694. [PubMed: 15471985]

Zhang AY, Yi F, Teggatz EG, Zou AP, Li PL. Enhanced production and action of cyclic ADP-ribose during oxidative stress in small bovine coronary arterial smooth muscle. Microvasc Res 2004;67:159-167. [PubMed: 15020207]

Zhang AY, Yi F, Zhang G, Gulbins E, Li PL. Lipid raft clustering and redox signaling platform formation in coronary arterial endothelial cells. Hypertension 2006a;47:74-80. [PubMed: 16344372]

Zhang F, Jin S, Yi F, Xia M, Dewey WL, Li PL. Local production of O2- by NAD(P)H oxidase in the sarcoplasmic reticulum of coronary arterial myocytes: cADPR-mediated $\mathrm{Ca} 2+$ regulation. Cell Signal 2008;20:637-644. [PubMed: 18207366]

Zhang F, Zhang G, Zhang AY, Koeberl MJ, Wallander E, Li PL. Production of NAADP and its role in $\mathrm{Ca} 2+$ mobilization associated with lysosomes in coronary arterial myocytes. Am J Physiol Heart Circ Physiol 2006b;291:H274-282. [PubMed: 16473958] 


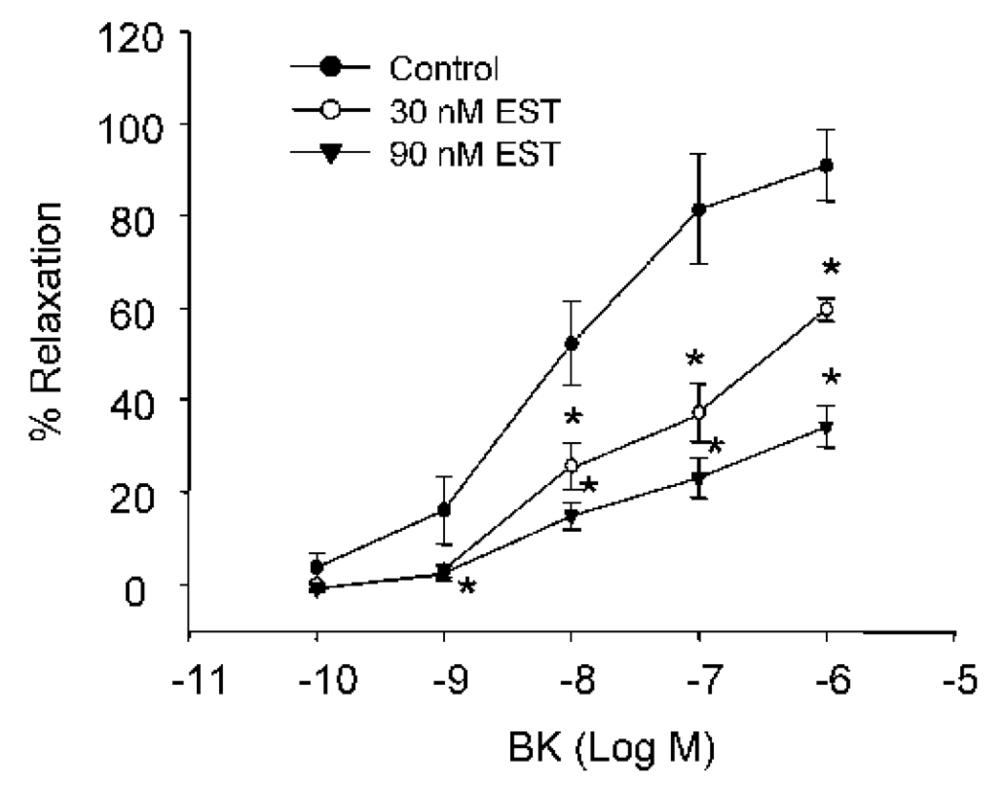

B

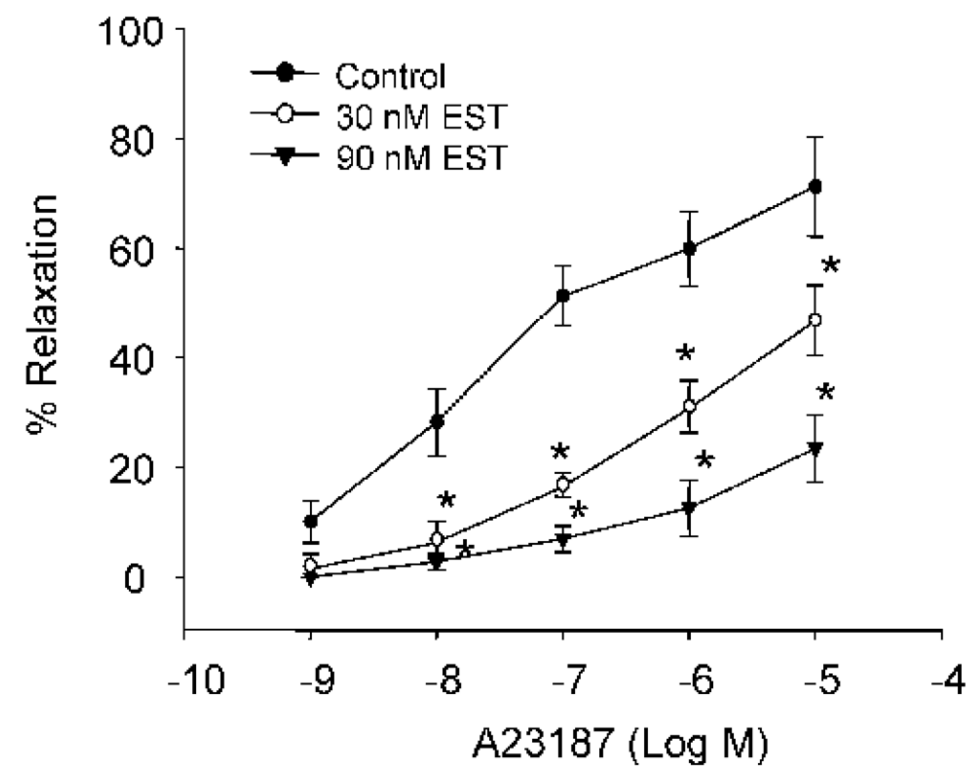

Figure 1.

Dose-dependent inhibition effects of endostatin on concentration-dependent vasodilator response in freshly isolated and pressurized small bovine coronary arteries. A: Effects of endostatin (30 and $90 \mathrm{nM}$ ) on vasodilator responses to BK with maximal inhibition of 34.14 $\pm 5.09 \%$ and $62.36 \pm 6.16 \%$ in 30 and $90 \mathrm{nM}$ endostatin group, respectively. B: Effects of endostatin (30 and $90 \mathrm{nM}$ ) on vasodilator responses to A23187 with maximal inhibition of $34.28 \pm 7.77 \%$ and $67.20 \pm 6.30 \%$ in 30 and $90 \mathrm{nM}$ endostatin group, respectively $(\mathrm{n}=6$ hearts, $* \mathrm{p}<0.05$ vs. control). 


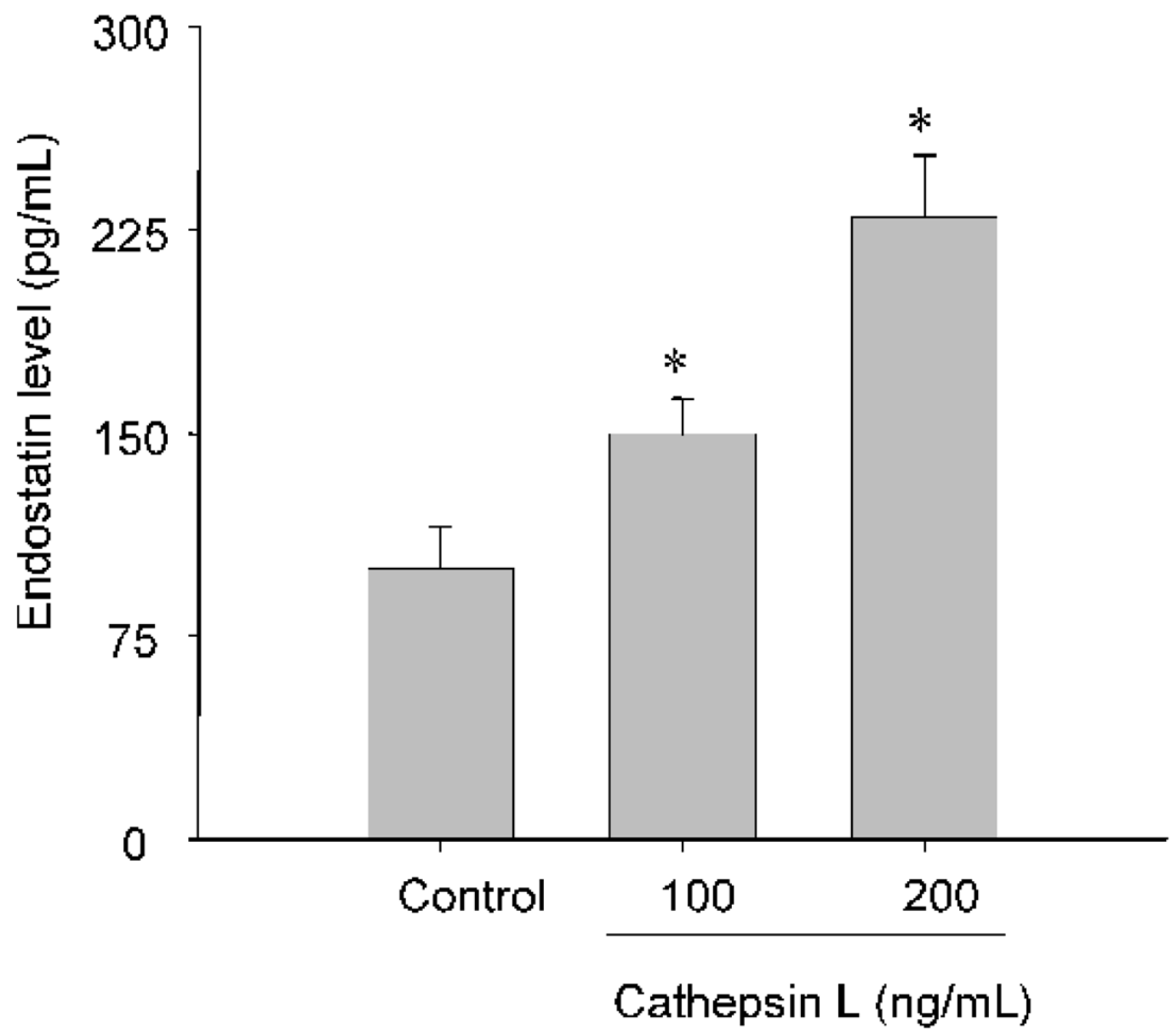

Figure 2.

Cathepsin L concentration-dependently increases endostatin production in bovine coronary artery homogenates by ELISA assay. Summarized data showing tissue level of endostatin markedly increased by about $50 \%$ and $130 \%$ in 100 and $200 \mathrm{ng} / \mathrm{ml}$ cathepsin L-treated group, respectively, compared with control $(\mathrm{n}=6, * \mathrm{P}<0.05$ vs. control). 

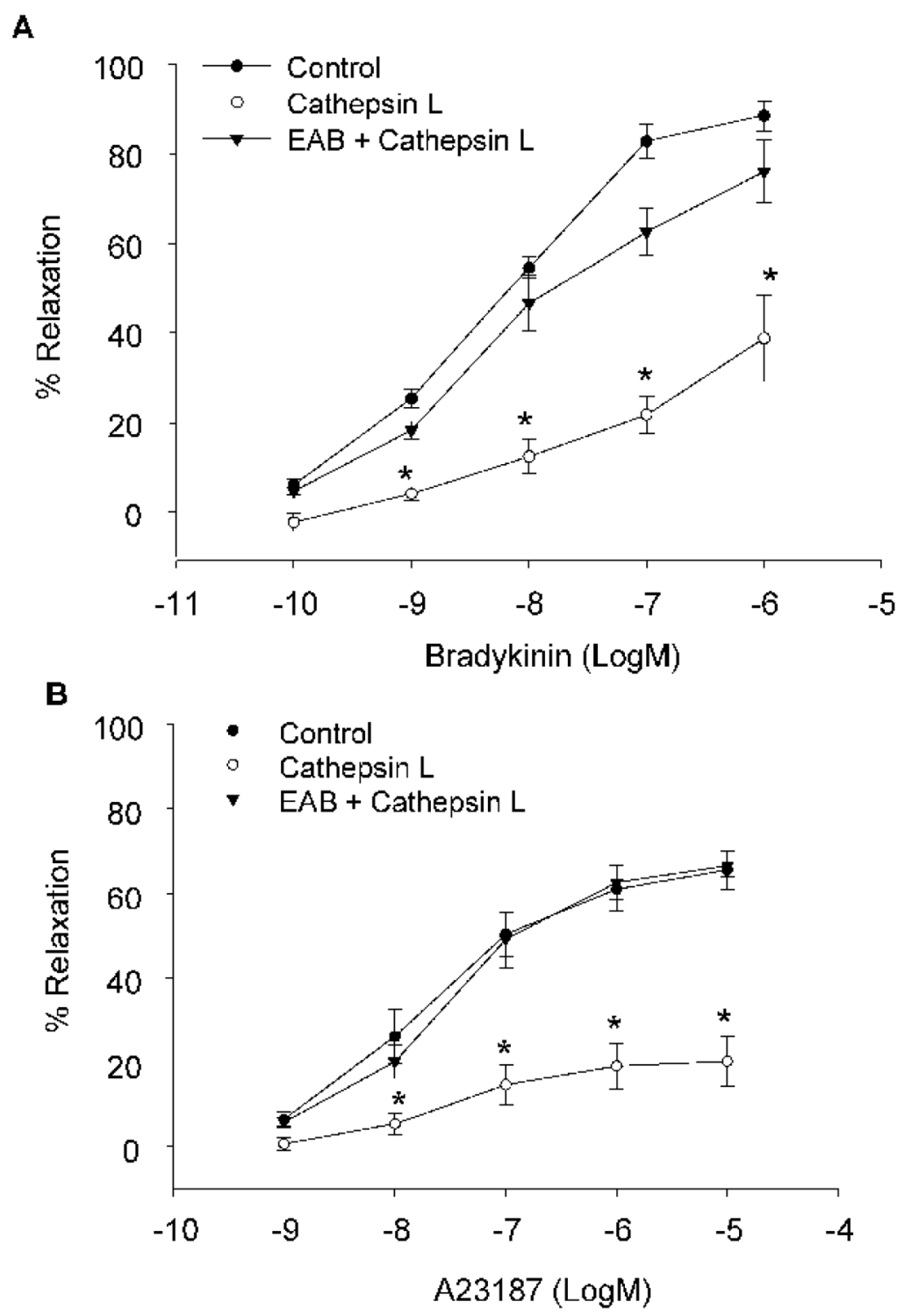

Figure 3.

Effects of anti-endostatin antibody $(\mathrm{EAB})$ on cathepsin L-induced vasodilation damage in small bovine coronary arteries. A: Cathepsin L alone significantly decreases BK induced vasodilation, pretreated with EAB $(10 \mu \mathrm{g} / \mathrm{ml})$ almost completely prevents cathepsin L ( $200 \mathrm{ng}$ / $\mathrm{ml}$ )-induced vasodilation damage to BK. B: Similarly, Cathepsin L alone significantly decreases A23187-induced vasodilation, whereas pretreatment with EAB $(10 \mu \mathrm{g} / \mathrm{ml})$ abolished cathepsin L (200ng/ml)-induced vasodilation damage to A23187 ( $\mathrm{n}=6$ hearts, * $\mathrm{p}<0.05$ vs. control. or $\mathrm{EAB}+$ Cathepsin L group). 
A

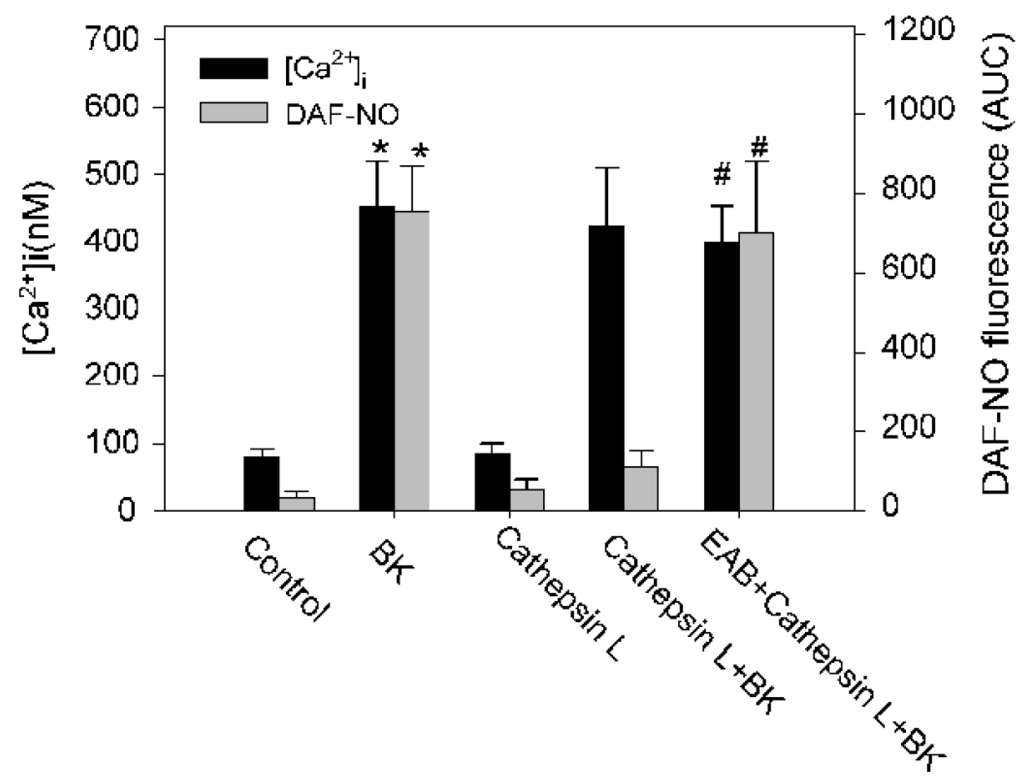

B

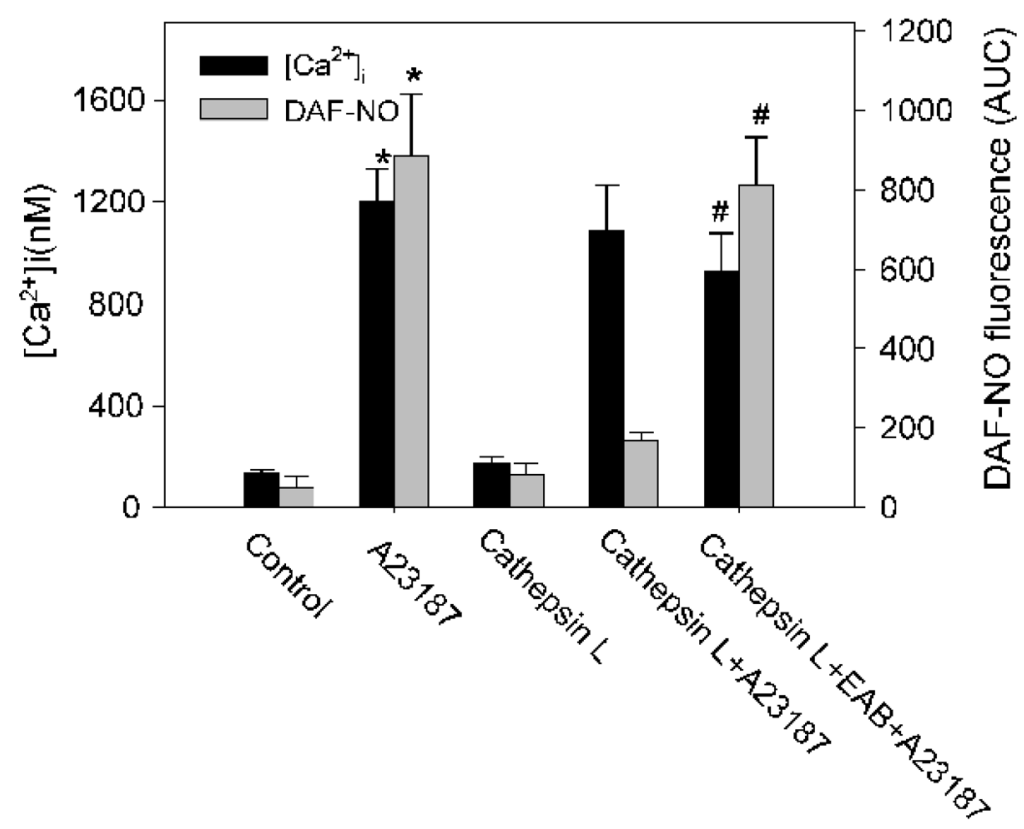

Figure 4.

Uncoupling effects of cathepsil $\mathrm{L}$ on vasodilators-induced increase in $\left[\mathrm{Ca}^{2+}\right]_{\mathrm{i}}$ and NO production [DAF-Fluorescence, area under the curve (AUC) in $30 \mathrm{~min}$ ] in intact endothelium of small coronary. BK or A23187 alone significantly increased $\left[\mathrm{Ca}^{2+}\right]_{\mathrm{i}}$ and DAF fluorescence. Pretreated with cathepsin L, either BK or A23187 no longer increased NO but still stimulated an increase in $\left[\mathrm{Ca}^{2+}\right]_{\mathrm{i}}$. However, in the presence of both anti-endostatin antibody (EAB) $(10$ $\mu \mathrm{g} / \mathrm{ml}$ ) and cathepsin L (200 ng/ml), BK or A23187 -induced NO production was restored to the level when the arteries were stimulated by BK or A23187 alone. A: BK treatment results, B: A23187 treatment results $(\mathrm{n}=6, * \mathrm{P}<0.05 v s$. control). 


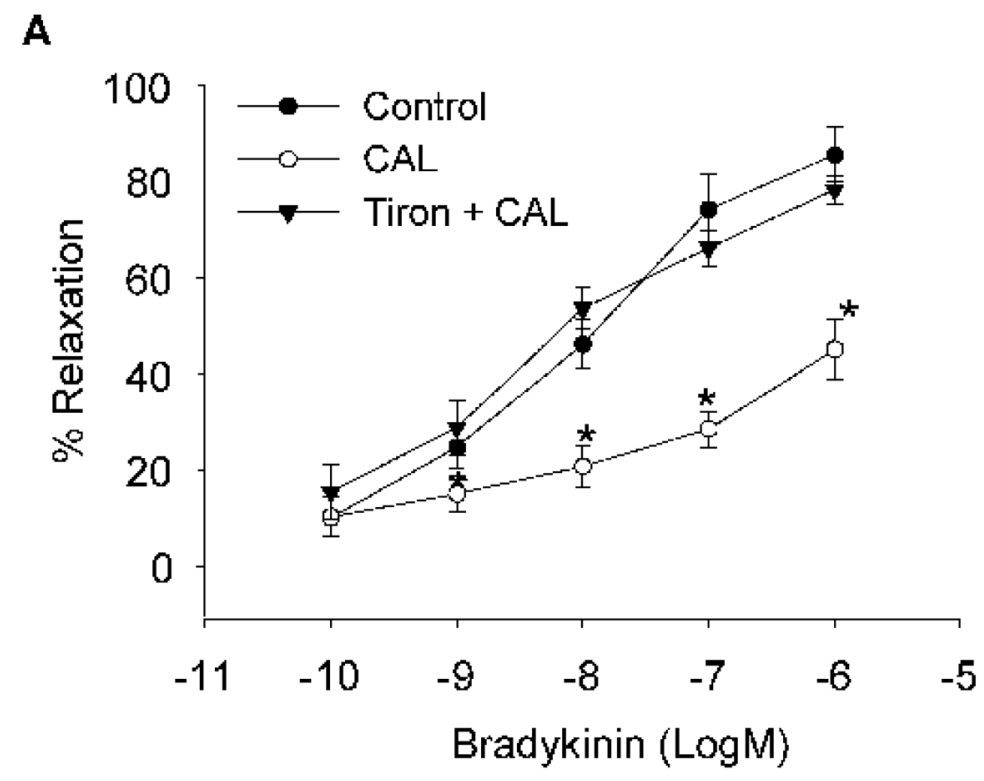

B

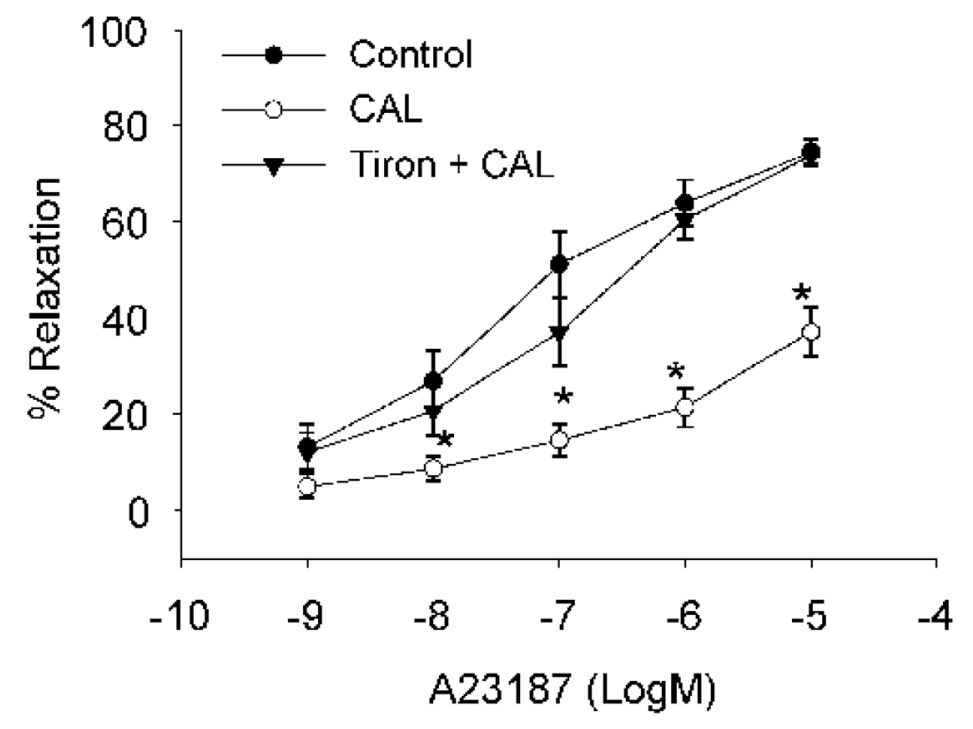

Figure 5.

Effects of SOD mimetic tiron on cathepsin L-induced impairment of the vasodilator responses. A: In Tiron + CAL (Cathepsin L) group, pretreated with Tiron (1 mM) almost completely prevent CAL-induced vasodilation damages to BK, compared with CAL alone. B: Similarly, in Tiron + CAL group, pretreated with Tiron $(1 \mathrm{mM})$ almost fully recover CAL-induced vasodilation damages to A23187 ( $\mathrm{n}=6$ hearts, * $\mathrm{p}<0.05$ vs. control. \# $\mathrm{p}>0.05$ vs. control or Tiron+CAL group). 
A

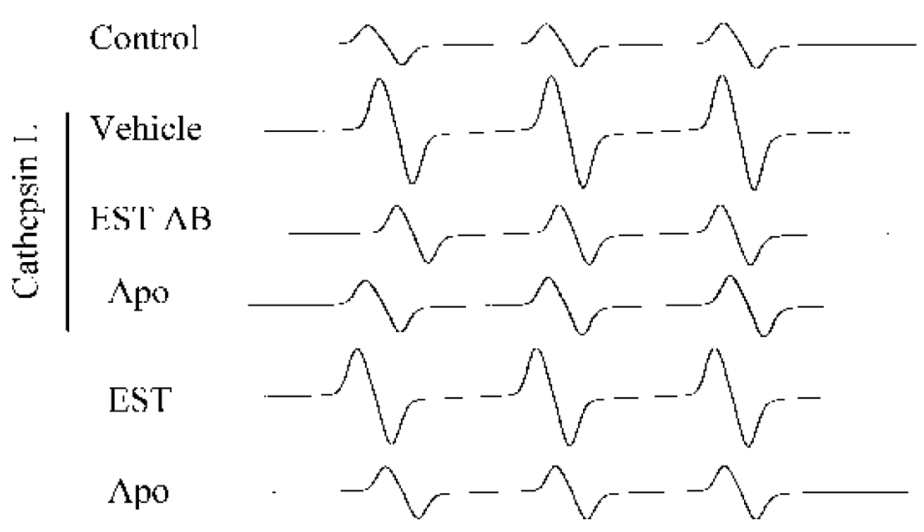

B

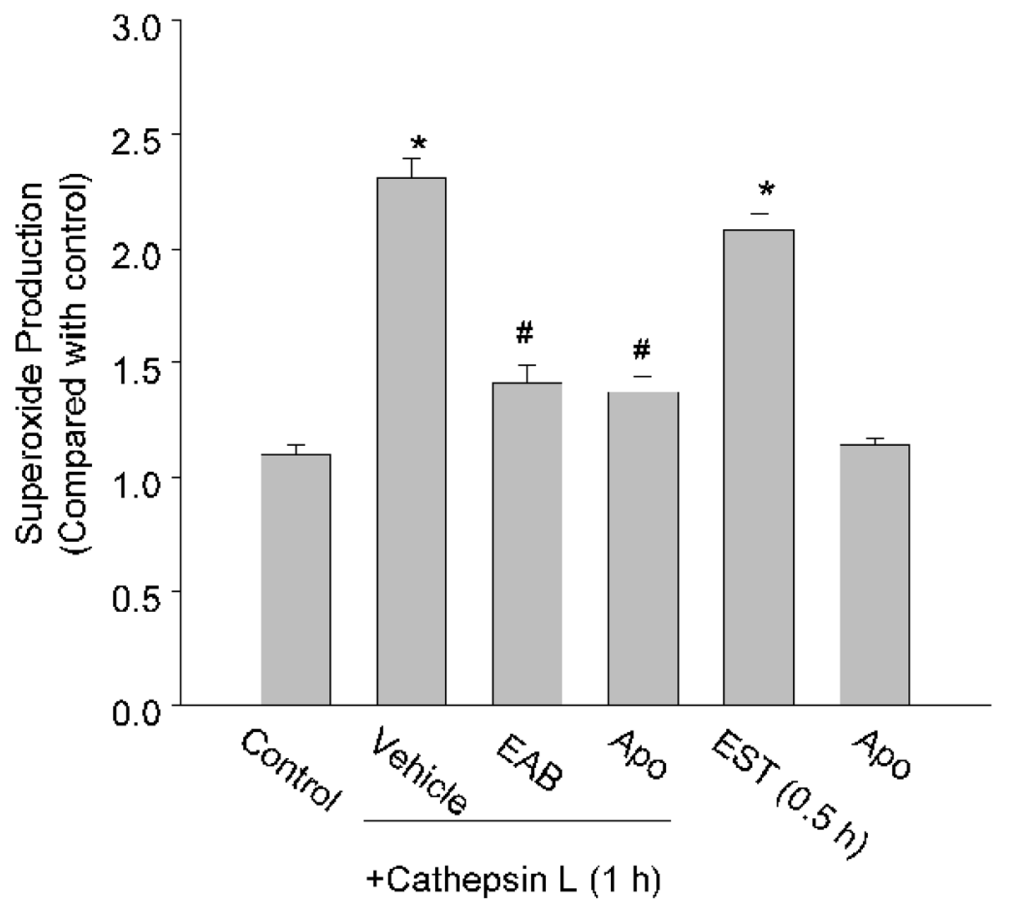

Figure 6.

Electron spin resonance (ESR) spectrometric analysis of $\mathrm{O}_{2}{ }^{-{ }^{-}}$production associated with NAD (P)H oxidase in bovine coronary arterial endothelial cells stimulated by endostatin and cathepsin L. A: representative ESR spectrographs of $\mathrm{O}_{2}{ }^{-{ }^{-}}$trapped by 1-hydroxy-3-

methoxycarbonyl-2,2,5,5-tetramethylpyrrolidine $(\mathrm{CMH})$ with $\mathrm{NAD}(\mathrm{P}) \mathrm{H}$ as substrate. B: Summarized data showing either cathepsin $\mathrm{L}$ or endostatin (EST) markedly increase $\mathrm{O}_{2}{ }^{--}$ production. Preatreatment of endothelial cells with endostatin antibody (EAB, $10 \mu \mathrm{g} / \mathrm{ml}$ ) or $\mathrm{NAD}(\mathrm{P}) \mathrm{H}$ oxidase inhibitor, apocynin $(\mathrm{Apo}, 100 \mu \mathrm{M})$, significantly attenuated cathepsin Linduced $\mathrm{O}_{2}{ }^{--}$production, whereas apocynin alone had no effects on basal $\mathrm{O}_{2}{ }^{--}$production $(\mathrm{n}=6$, $* \mathrm{P}<0.05$ vs. control, \#P $<0.05$ vs. EST alone group). 